\title{
Climates of History, Histories of Climate: From History to Archaeoscience
}

\section{Citation}

McCormick, Michael. 2019. Climates of History, Histories of Climate: From History to Archaeoscience. Journal of Interdisciplinary History 50, no. 1: 3-30.

\section{Permanent link}

http://nrs.harvard.edu/urn-3:HUL.InstRepos:42656646

\section{Terms of Use}

This article was downloaded from Harvard University's DASH repository, and is made available under the terms and conditions applicable to Open Access Policy Articles, as set forth at http:// nrs.harvard.edu/urn-3:HUL.InstRepos:dash.current.terms-of-use\#OAP

\section{Share Your Story}

The Harvard community has made this article openly available.

Please share how this access benefits you. Submit a story.

\section{Accessibility}


Journal of Interdisciplinary History, L:1 (Summer, 2019), 3-30

The 50th Year: Special Essay 1

\section{Climates of History, Histories of Climate: From History to Archaeoscience}

Today we have entered an era of historical discovery that reaches far beyond the study of ancient climates and modern connections. In a world of learning increasingly blinded by short-sighted metrics of productivity, translational science, and "impact," emerging transdisciplinary paleoclimate studies exemplify the creative power of curiosity-driven research to understand some of the most important—indeed, potentially civilization-altering — phenomena in the world in which we and our successors must live. Transdisciplinary research — that is, research encompassing and transcending two, three, or more disciplines and asking wholly new questions - depends on humanists and on scientists.

Michael McCormick is Francis Goelet Professor of Medieval History, Harvard University, and Co-Director of the Max Planck-Harvard Research Center for the Archaeoscience of the Ancient Mediterranean Initiative for the Science of the Human Past. He is the author of Charlemagne's Survey of the Holy Land: Wealth, Personnel and Buildings of a Mediterranean Church between Antiquity and the Middle Ages (Cambridge, Mass., 2011); Origins of the European Economy. Communications and Commerce, A.D. 300-900 (New York, 2001); co-author of "The Climate and Environment of Byzantine Anatolia: Integrating Science, History, and Archaeology,” Journal of Interdisciplinary History, XLV (2015), 113-161.

c 2019 by the Massachusetts Institute of Technology and The Journal of Interdisciplinary History, Inc. 
The discovery of how humans experienced ancient climates is part of a broader deployment of science to expand the frontiers of historical knowledge. Cascading breakthroughs characterize ancient DNA studies - especially the last few years' technological and intellectual advances of the genomic revolution that have unveiled humanity's deep history — and biomolecular archaeology's recovery of ancient biomes and molecules more generally. Paleoclimate science, too, is transforming our knowledge of the relations between human societies and past climates. By adducing new unanticipated data, the scientific revolution now affecting historical research promises to disrupt, creatively, what we thought we knew about the human past. But the challenges of integrating scientific evidence into historical analysis call for new approaches suited to a new historical discipline that we may broadly characterize as archaeoscience. $^{1}$

Knowledge of past environments has grown by studying nature through history and by studying history through nature. This sketch is perforce incomplete: Publications proliferate too fast to do justice to all that has appeared. In this journal's last five volumes alone, more than a dozen articles have focused on climate and history. The sketch will also be a little personal, in the hope that one scholar's experience can serve others. But that brings another limitation; it reflects a perspective largely confined to the ancient and medieval civilizations of western Eurasia. $^{2}$

NATURE FROM HISTORY The study of climate in history has been around for a long time, but it accelerated in the 1960s. National scientific societies in the United States organized exploratory conferences in 1962 on the paleoclimatology of the eleventh to the sixteenth centuries A.D., and in the United Kingdom in 1966 on climate from 8000 to "0" в.C. Around that time, most 
scholars inclined to the view that climate during the last 10,000 years or so has largely been unchanging. Only a very few, like Carpenter (1889-1980), challenged the conventional wisdom. Carpenter notably cited Herodotus 7.171 on the famine and pestilence that desolated Crete after the Trojan War, as well as evidence that he had collected from climatological studies, to deduce drought c. 1200 B.C. as the root of the Mycenaean collapse known from archaeology. ${ }^{3}$

Two figures were pivotal in alerting historians to the possibilities of climate for studying historical change. In Britain, Lamb (1913-1997), a distinguished climatologist, ingeniously evaluated scattered anecdotes of weather events recorded in historical records to exercise his deep understanding of climate patterns. His broad syntheses opened the eyes of many scholars (including this one) to climate's historical potential. In France, Fernand Braudel (1902-1985) and the Annales school extended the historian's remit to include the natural environment along with long-lived economic and cultural structures. Braudel famously laid out the environmental framework of Mediterranean history, and, ten years later, Le Roy Ladurie's innovations in medieval agrarian and environmental history produced the landmark "History of the Climate after 1000.” Important contributions multiplied thereafter-for example, Pfister's work in Switzerland (1975 and 1984) and Alexandre's in Belgium (1976 and 1987). Alexandre's critical catalog of historical testimony about weather events provided an invaluable reference work for medieval climate history. Pfister successfully developed fine-grained monographs about early modern climate variability and social and economic responses, creating, with his collaborators, research tools for other scholars' benefit (see below). Engagement with climate as a historical problem was also emerging in other scholarly traditions, such as the work on China by Zhu Kezhen (1890-1974). ${ }^{4}$ 
By 1979, what we might call the historians' history of climate was generating enough interest that this journal devoted a conference and a prescient issue to the theme, including Le Roy Ladurie's contribution about the dates of French wine harvests since the fifteenth century as a proxy for summer weather. Beyond Lamb, climatologists were also availing themselves of historical records. In 1984, NASA scientist Richard Stothers turned to four late antique eyewitnesses to establish the character and potential impact of the "536 event" (see below), which he identified to be volcanic, as ice-core research has recently confirmed. Rich though it was, the initial harvest was limited nevertheless by what Le Roy Ladurie evocatively called "the sound barrier" of the year 1000. Historians relying on written evidence had difficulty pushing further back into the first millennium of our era for which such sources have survived less abundantly, at least in western Eurasia. ${ }^{5}$

HISTORY FROM NATURE Independently of environmentally curious historians, the explosive growth of scientific and technological innovation from or starting in the 1960s and 1970s accelerated modern climate science. Satellite-based instrumentation multiplied many-fold the quantity, quality, and geographical scope of measurements pertaining to ongoing climate phenomena. New measurements signaled unexpected phenomena in the present and recent past. Cascading observations and efforts to detect systems and mechanisms and to distinguish random variation from causal chains or systemic shifts drove the insight that understanding current data required a time scale deeper than the existing instrumental records. Thus began the hunt for "proxy" measures, natural archives generated by natural phenomena that could be understood to preserve some kind of climate signal. To gauge the significance of increasing quantities of precise and continuous measurements of today's climate with growing global coverage, earth 
scientists began to develop their own history of climate by identifying proxy witnesses reflecting precipitation, temperature, or movements of air masses before the instrumental era. Constructing such long-term records is essential to assessing the abnormality of emergent patterns detected by instruments measuring present-day climate change.

Identification of environmentally driven variation in the formation of various natural organisms and deposits has made tremendous progress since this journal's special issue of 1980 presented what was then known about solar activity, botanical data, tree rings, and isotopes. Recent work has vastly expanded these natural archives, added new ones, elucidated their mechanisms, and better calibrated the amplitude of the proxy witnesses' signals against the record of ever-lengthening instrumental measurements. Tree rings, ice cores, limestone cave deposits, and lake sediments are among the most widely deployed proxies in historical studies today; all of them, save glacier ice cores, are relatively well distributed across Eurasia. ${ }^{6}$

Tree Rings Tree rings were one of earliest proxy sources, and they remain one of the most powerful. Again, curiosity-driven science led to breakthroughs that transformed the evidentiary basis for understanding climate. From the last century's early years, Douglass (18671962), an astronomer, investigated sunspot cycles from tree rings. Demonstrating climatic effects on long series of tree rings further opened his eyes to the possibility of using rings' time-stamped variations to date the enigmatic Amerindian ruins in the U.S. Southwest where he was working. Efforts to build tree-ring inventories that went far back in time and to replicate trees where they once grew spread across Europe in the post-World War II years, particularly in the Germanspeaking lands, Scandinavia, and the British Isles; the areas around the Mediterranean, with one or two notable exceptions, have lagged considerably. Properly developed and analyzed, tree rings can resolve to absolutely dated individual years. They allow robust proxy reconstructions 
of precipitation and even temperature for some areas that are absolutely dated as far back as 2,500 years. Of particular value to historians and archaeologists are Cook's comprehensive historical atlases of annual precipitation reconstruction created throughout decades of dendroecological research, which are freely available online. ${ }^{7}$

Ice Cores Ice cores drilled in glaciers capture the atmospheric chemistry trapped in snow that fell and transformed into ice. They offer an exceptionally wide spectrum of proxy indicators of ancient environments, including volcanic activity, temperatures, movements of air masses, and atmospheric deposition of anthropogenic pollutants such as lead. In the best cases, ice cores display annual or, lately, sub-annual resolutions capable of correlation with geological (volcanic eruptions) or historical events sometimes down to the exact year or season. Until 2017, most ice-core evidence of interest to historians came from the great glaciers of Greenland and Antarctica, which are $3 \mathrm{~km}$ deep and cover c. 100,000 years of climate in Greenland and 800,000 in Antarctica. Greenland's ice cores preserve high accumulations of snow, thus forming deep annual ice layers large enough for detection by standard technology - Continuous Flow Analysis—at resolutions of c. $1.0 \mathrm{~cm} .^{8}$

The polar cores have the disadvantage of being remote from the main theaters of human history; they often capture atmospherically transported markers from an entire hemisphere or more (and therefore blur their specific geographical origins). Because they are much smaller and their older ice layers highly compressed and thin, more strategically situated glaciers from the Alps, for example, have not yielded, until last year, useful signals dating back more than a few hundred years. Now, however, next-generation technology — in the form of ultra-high-resolution analysis developed by the Climate Change Institute (CCI) of the University of Maine- has opened the way to recovering new historically datable environmental and cultural records from 
ancient ice in the heart of Europe and elsewhere. This technology has found its first major application in the Maine-Harvard Historical Ice Core Project (see below). ${ }^{9}$

Speleothems, Sedimentary Deposits, Pollen, et al. Other natural archives are also accumulating. Speleothems - limestone cave deposits, typically stalagmites, arising from groundwater percolation - form in patterns that can be annual or even sub-annual. They are capable of providing insight into precipitation and temperature through the isotopic ratios of key elements and datable through such advanced techniques as Uranium-Thorium dating. Sedimentary deposits on lake bottoms are sometimes annually sealed (varves), preserving various atmospherically transported deposits. Fossilized pollen trapped there yields information about, among other things, plant spectra. As a sensitive indicator of the human impact on a botanical community at a given time, they can reveal, say, the expansion or contraction of woodland at the expense of cultivation or changing preferences in cultivated plants. Pollen spectra, however, typically register only changes in temperature and precipitation that are dramatic enough to alter the plant community; rarely do sedimentary deposits achieve a chronological resolution superior to that of radiocarbon dating. Other well-established or emerging methods continue to provide new data sets that enrich our knowledge about climates of the past, from cosmogenic isotopes (for example, ${ }^{14} \mathrm{C}$ ) to archaeologically recovered insects or marine sediments. Certain clams (Arctica islandica) turn out to have annual rings with isotopic ratios that can serve to reconstruct ocean temperatures, a key factor in global climate. ${ }^{10}$

A final tool for reconstructing ancient climates comes from the increasing power of climate analysis and modeling. As computing power and speed mount, models absorb and manipulate ever-growing amounts of emerging high-quality data. Mathematical simulation of climate patterns allows us increasingly to model them and thereby test possible connections and 
correlations between signals and climate structure, as well as their consequences. Unfortunately, most such programs are not openly available for scholars' experimentation. A notable exception is the CCI's Climate Re-AnalyzerTM, which allows users to examine and simulate climate patterns with different boundary conditions. ${ }^{11}$

Notwithstanding these impressive new data, many climate scientists recognize that human beings recording conditions in a particular time and place are the most powerful paleoclimate proxies. Scientists have therefore welcomed the collaboration of professional historians and archaeologists to help them to understand the "fuzzy data" that are the hallmark of human history. Rich though it be, the testimony of rare words in ancient languages or of structural remains in ancient landscapes can be challenging. Collaborative research that integrates the different methods and data of historians, archaeologists, philologists, and scientists is the way of the future.

NASCENT SYNTHESIS: THE CONSILIENCE OF THE HUMANITIES AND SCIENCES

From these separate efforts have come research tools that lay the foundation for new discoveries. Since c. 1900 at least, scholars have cataloged written reports about climate. Hennig (1874-1951) published a preliminary inventory of weather events in 1904. Expanding on this foundation was the useful but sometimes uncritical multi-volume omnium-gatherum of reports from the beginning of the Christian era until 1850 initially collected by Weikinn (1888-1966), a dedicated amateur. Alexandre, a medievalist, produced a resource with an unprecedented level of detail and quality for Europe from 1000 to 1425 A.D. Although the languages of their publication lessen the influence that they deserve to exert, high-quality repertories of written evidence have appeared recently for the Low Countries (763-1800, so far) and the Byzantine Empire and its neighbors 
(300 to 1479). That these valuable contributions currently exist only in printed form limits their usefulness for twenty-first-century research, although efforts are afoot to create online analogs of these pioneering efforts. ${ }^{12}$

Although it is often impossible digitally to search, correct, concatenate, or mathematically to correlate printed or restricted works online with new, especially scientific, proxy data, Pfister and his team at the University of Bern has made its Euro-Climhist Database, initiated in the 1970s, available on the website of the NOAA National Centers for Environmental Information, Paleoclimatology Data. Whatever online websites they may choose to develop, historians of climate should emulate their colleagues in climate science by making their data freely available for direct download and analysis. As a case in point, a Franco-Spanish group in 2012 prepared and shared through open access a grape-harvest database offering precious proxies for summer warmth as far back as 1354 A.D. In 2016, German historians made freely available German translations of a rich collection of Arabic and other Middle Eastern environmental reports covering 801 to 1821 A.D. that they had developed over several decades. ${ }^{13}$

The Science of the Human Past (SOHP) Digital Atlas team at Harvard University has been endeavoring to do likewise since 2011. Among the draft historical-climate data sets that this student-teacher team has created, and that any user can download by clicking a button, are written sources for Central European extreme precipitation from 1013 to 1504 A.D. (2011), climate events under the Roman Empire from 100 B.C. to 800 A.D. (2012), climate events from 800 to 1300 A.D. (2016), and climate reports for the same period (2016). All of them, which build on the commendable printed work of our predecessors, are available to be edited and developed freely under a "Creative Commons" license. As swiftly as our modest resources allow, we aim to produce and distribute our data sets ultimately as geodatabases - that is, data 
sets geocoded for digital latitude and longitude - in order to allow spatial as well as temporal analysis. We hope to be able to continue improving these drafts. We uploaded them as soon as possible so that others could use them right away. Many of us began our careers when printing texts on paper, the only option, was expensive and cumbersome, and the results had to be as close to perfect as possible, since it was often too costly to print corrections and new editions. Today, because digital publication online has banished most expenses beyond the time and scholarly effort required to prepare original versions and subsequent revisions, our new data sets can appear almost immediately, ready for broader use. ${ }^{14}$

One challenge that historians face in producing data sets for the natural sciences arises from our expertise in dealing with the fuzzy data that characterize human discourse. In producing a critical record of historical evidence about climate, we must take into account the needs of climatologists, economists, and political scientists in addition to respecting the demands of our own discipline. Reflecting our complex sources, we historians sometimes formulate our observations in elaborate, nuanced, and even ambiguous terms, in ways that can frustrate our colleagues in other disciplines. As Lamb saw long ago, our best research will be useless to scientists unless we evaluate phenomena in a way that lends itself to numerical analysis. Our classifications must be as rigorous as possible, using even simple numerical values — say, a scale from 1 to 4, from "least strong" to "strongest." They should describe, at a minimum, the reliability of the records at hand, as well as the nature, strength, and spatio-temporal extent of the phenomena recorded. Users should be able to adapt downloadable data sets according to the different schemes that they devise; the key requirement is that the testimony be classified as consistently as possible and that the classifications be explained clearly. No less importantly, if the connections that historians make are to find acceptance among scientists, they must be 
subjected to testing with the statistical methods that are de rigueur in the sciences, whenever feasible. ${ }^{15}$

At one level, the work of historians should be joyfully ancillary and creatively critical; written evidence can verify the accuracy of the climate phenomena that scientists deduce from comparing modern instrumental readings and scientific proxies. For example, a few years ago, historical records elegantly confirmed the dendroecological reconstruction of spring precipitation in northeastern France, as well as in northeastern and southeastern Germany, from 250 B.C. to 2000 A.D. based on the analysis of 7,000 tree-ring series.

I then asked dendroecologists for records about all the later medieval extreme droughts and rainfalls deduced from the tree rings, expecting the relevant written records to be strong enough to test whether eyewitnesses in the same places where the trees were located actually observed the extreme rainfall or drought that the dendroecologists had gleaned from the rings. Büntgen identified thirty-two extreme precipitation years from 1013 to 1504 A.D., for which I was able to locate eighty-eight such eyewitness accounts. For thirty of those thirty-two years, at least one medieval written record reported the same precipitation extreme as the scientists deduced from the tree rings, independently confirming the accuracy of the dendro-reconstruction of spring precipitation. ${ }^{16}$

This collaboration of humanists and scientists illustrates one response to Wilson's eloquent call for reuniting the "Two Cultures" of humanists and scientists through consilience. Consilience arises when independent approaches allow distinct analyses to "jump together" (Latin consalire) in a transdisciplinary conclusion for which the probative power resides in the emergence of the same results from independent investigations in independent disciplines from 
independent evidence. The results both stem from and confirm the unity of the reality that each investigation observes on its own. ${ }^{17}$

Thus, we can use our written records to test and reinforce results achieved through scientific methods. But even more important for historians seeking to clarify the environmental context is the unavoidable fact that the historical record does not by itself afford a complete understanding of climates before recent times. The ancient and medieval written sources may be richer than is often supposed, but they are uneven. Because wide and unpredictable gaps undercut the coverage of most periods and phenomena, arguments from silence are usually precarious. We cannot therefore build a climate history from the written records alone, especially, as Le Roy Ladurie emphasized, before 1000 A.D. To go deeper, we must integrate our historical record with the scientific signals of climate deduced from natural-proxy archives, which expands the detailed climate horizons presently available to us beyond a few centuries to 2,000 years or more. ${ }^{18}$

An early hint of the historical potential of the new data came during the 1990s from the detection of atmospheric depositions of lead and copper in a Greenland ice core that seemed to show broad associations with suspected patterns of ancient and medieval metal production in western Eurasia and China. Similar evidence from bog and other sedimentary deposits pointed in the same direction, but such deposits generally lack the kind of chronological resolution that is indispensable to advanced historical investigation. However, the new instrument for Laser Ablation Inductively Coupled Mass Spectrometry (LA-ICP-MS), developed by the CCI, ?? has successfully crossed the old threshold of chronological specificity. This is crucial for the highly compressed European ice cores.. Whereas standard technologies could make 100 measurements in $1 \mathrm{~m}$ of ice core, the new system allows as many as 50,000 measurements in $1 \mathrm{~m}$, meaning that 
it can detect distinct annual signals, seasonality, and even storm events in very thin ice layers, such as those that typify European glaciers. Thus, the Maine-Harvard Historical Ice Core Project, was able to identify the Black Death's arrival in a new core from Switzerland recovered with our European collaborators.

While the team members at CCI are using its new technology to make the most detailed measurements ever conducted on an ice core, including of lead deposits, the team members at SoHP are assembling the relevant historical and archaeological evidence. Both groups come together to analyze the data, synthesize the results, and write each study. Their precise, subannual environmental measurements_-290 measurements for the year 1349 alone_-indubitably reflecting the regional conditions in western Europe, are game-changing. The opening historical study, led by More, focused on the new measurements of atmospheric deposits of lead pollution at the Colle Gnifetti glacier in the Swiss Alps that originated in British mining and ore processing. They depict in graphic terms how production collapsed in the spring and summer of 1349 as the Black Death devastated the working population. The measurements echo, clarify, and deepen the disparate evidence of archaeology and written sources (see Figure 1). This date marked the only time in the last 2,000 years when atmospherically deposited lead pollution from metal production dropped to undetectable levels on this glacier. ${ }^{19}$

Fig. 1 Lead Concentration in the Ice Core from Colle Gnifetti (Switzerland), from UltraHigh-Resolution LA-ICP-MS, 1330-1360 A.D. (Historical Ice Core Project) 


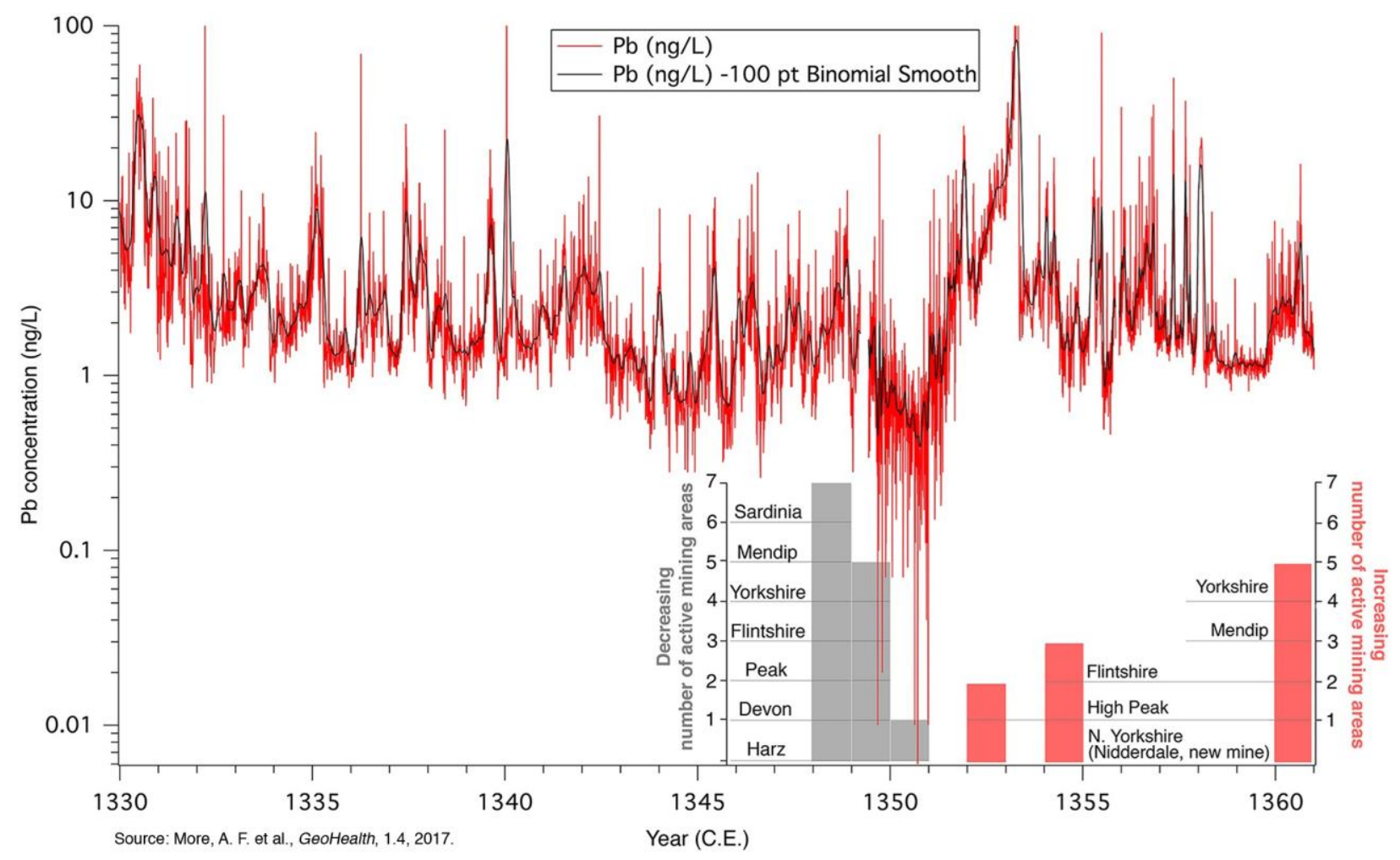

NOTES The average measurements per year in from 1349 to 1353 are 279. The grey histogram represents the declining number of active major mining regions as they were progressively hit by the plague and ceased operations; the red histogram represents the number of mining regions resuming metal production, based on written sources. At present, because no estimates of volume of aggregate metal production are available, the histograms reflect only regions that were active, not the volume of lead produced. Smoothing (black line) is provided only as a visual aid; the red plot presents the raw data.

SOURCE Figure and legend adapted from Alexander F. More, Nicole E. Spaulding, et al., "Next Generation Ice Core Technology Reveals True Minimum Natural Levels of Lead $(\mathrm{Pb})$ in the Atmosphere: Insights from the Black Death,” GeoHealth, I (2017), 215 (Figure 5, reproduced with the permission of GeoHealth). 
As the Historical Ice Core Project proceeds more deeply into the past, it is uncovering further environmental data that illuminate economic history, among other areas. Since lead is often associated geologically with silver, the mining and production of silver can produce lead, and pollution, as a by-product. Hence, the project throws bright new light on the epochal shift of the seventh-century European economy from the Roman gold standard to the silver coinage that fueled Europe's medieval growth. Some historians have suspected, and others have denied, that new silver mines drove this major systemic change. The last decades' striking archaeological and numismatic discoveries about the new Merovingian and Carolingian lead and silver mines of central France, at Melle (Deux-Sèvres), directly upwind of Colle Gnifetti, have not resolved the question. Now, however, the team's measurements show that lead deposition on that glacier spiked sharply in just the decades in which seventh-century Merovingian minters first debased the kingdom's gold coins with silver, and then again as they shifted outright to purely silver coins, certainly reflecting the expansion of silver production at Melle. Hence, the new evidence from the Historical Ice Core Project proves that, in this case, new silver mining did indeed play a crucial role in Europe's shift to the silver standard that prevailed for the next seven centuries. With other, more distant but more voluminous polar ice cores, the older methods continue to give promising results at the convergence of environmental and economic history, elaborated by other interdisciplinary teams of scientists and humanists as new archaeo-scientific collaborations spread. $^{20}$

Perhaps because their disciplinary focus on material encourages recourse to advanced technologies, archaeologists have preceded humanists in integrating scientific data about climate into their studies. A remarkable example of the disruptive power of the new approaches came from Old World archaeology in 1993, when Weiss and colleagues published evidence for a 
severe aridization event c. 2200 B.C., based on fine soil-depositional patterns and archaeological indications, linking it with the collapse of the Akkadian civilization. Subsequent research has discovered this event to have been hemispheric, stretching from Spain to China via the Indus Valley, even as the initial study alerted scholars to the potential of abrupt climate change, and the human response to it, to shape the rise and fall of civilizations. ${ }^{21}$

New World archaeology has not trailed behind. Although a possible climate component had been adumbrated as early as 1973, earth scientists breathed new life into the debate about the collapse of Classic Maya Civilization (c. $750-1050$ C.E.) in 1995, when they identified evidence for a mega-drought. Less than a decade later, a dendrochronologist and a physicist in Cologne worked together to draw correlations between fluctuating tree-ring growth and historically documented grain-harvest variations in the early modern era. Collaborating with archaeologists, they used dendrodata to propose climate-driven changes in grain production during the Roman Empire as well as during the Linear Pottery Culture (Linearbandkeramik) of Europe's first farmers (5500-4500 B.C.). ${ }^{22}$

In 2004, a study of the relationship between Roman archaeological features and changing levels of the Dead Sea brought new data and questions into the developing climate history of the Levant. In October 2005, a workshop at Harvard University convened historians, archaeologists, and scientists to brainstorm about using paleoclimate proxy data more broadly to study premodern economies and societies. In addition to the many ideas that it generated, the meeting spawned one of the first studies to use an ice core to identify specific environmental causes of historical events, in particular the extreme volcanic eruptions that induced harsh winters, crop failures, and political and economic consequences in Charlemagne's empire and Byzantium. The integration of evidence from medieval annals and from ice-core measurements of the acidity 
deposited by volcanic eruptions - which were known to block solar radiation and cause sudden downturns in temperature-revealed a new causal pattern within historical events for which previously only random environmental conditions had been visible. Unexpectedly, scientific measurements made in Greenland in the 1990s helped to explain medieval history. In the same years, scholars probed more broadly and creatively the cultural impact and response of indubitable major shifts in climate regime, such as the late medieval and early modern Little Ice Age. $^{23}$

Four Research Trends Throughout the last decade, several trends have emerged in research integrating scientific and historical approaches. The first consists of efforts to establish from scientific data — buttressed by historical evidence when feasible — the basic climate characteristics that prevailed at particular moments in history as a first step toward understanding the interaction of climate change and societal developments. In 2011, an international climatological team updated what we knew about the Medieval Climate Anomaly (MCA) and the favorable conditions that characterized Europe's central Middle Ages. In 2012, a four-year-long effort by historians and climatologists culminated in the first scientifically grounded reconstruction of changing climate conditions across the Roman Empire and its successor states, and was published in this journal; an update with the latest evidence has just appeared. By 2014, the first of the regional syntheses of climate conditions in the Roman sphere heralded in that 2012 study had become a reality, also appearing in the pages of this journal. Two years later, a group of climatologists and a few historians produced a journal special issue that helpfully synthesized the climate history, and signs of the human response to it or lack thereof, in multiple Mediterranean regions during selected periods from prehistory to today. ${ }^{24}$ 
In 2016, the disruptive power of new scientific measurements showed itself again, identifying a new late antique Little Ice Age in which average summer temperatures dropped markedly across western Eurasia from 536 to c. 660/680. The newly observed conditions invite deeper investigation of potential links between this rapid climate change and the far-reaching societal reorganizations underway in those years, when the Roman Empire's reconquest of its western provinces ground to a halt and the migrations of the Slavs, Avars, and Arabs began. ${ }^{25}$

A second, most likely short-lived, trend arose as alert historians quickly brought the new proxy data deriving from paleoclimate science together with historical evidence to propose bold new explanations for major historical developments. In 2009, Bulliett consulted Near Eastern chronicles and Chinese tree rings to argue that an anomalous Siberian High obtruded over Iran in the tenth and eleventh centuries, ruining cotton production and creating difficulties for cameldependent populations. The upshot was a series of economic and political collapses. Deeper scrutiny, however, has come to challenge that perspective, finding the climate evidence to be weak and the historical evidence to indicate a different chronology and the predominance of political and military causes. In 2012, Ellenblum formulated a bold thesis that climate change drove wide-ranging historical change across the eastern Mediterranean. Whatever the fate of some of his more sweeping claims, the striking, and hitherto unnoticed, simultaneity of many of the key developments tracked in his book is not to be denied. ${ }^{26}$

A third trend concerns the syntheses that exploit historical as well as scientific evidence to re-situate broad swaths of human history in a new environmental matrix. Fagan's early surveys performed a signal service by introducing the cultivated public to a compelling vision of historical climate change. Brooke's 2014 Climate Change and the Course of Human History offers a good point of entry for humanists eager to immerse themselves in the evolving 
integration of scientific and historical climate approaches. It connects a conscientious study of recent paleoclimate science with an overarching trajectory of human development from its origins in Africa to its current stage in the world of the twenty-first century. Unavoidably, today's supercharged progress in paleoclimatic investigation already dates some of the scientific components of Brooke's discussion, But his fusion of science and history, among other things, encourages a view of human history and climate change in the stark terms of two epochs. In the immensely long first epoch the human response to the environment was limited to the voluntary migration and involuntary genetic change of small groups of hominins; they were trapped, went extinct, or evolved to spread new genetic features through founders' effects in resurgent micropopulations. The second, briefer epoch of human history and cultural resilience, in which we live now, is characterized by the march of technologies — shelter, clothing, heating, etc. - that can mitigate climate change to one extent or another. ${ }^{27}$

As this vision of two epochs suggests, scientifically informed climate history provides new alternatives for arranging our thinking about how the human experience unfolded over time. Periodization is a blunt but useful tool for organizing our knowledge of the past. Beyond the dynasties and the political, economic, and cultural structures that have underpinned existing schemes, paleoclimate science offers benchmarks of change derived from completely independent evidence, to lay alongside those that have already been adopted with success.

Giving priority to particular intervals of climate change makes obvious sense for historical studies that focus on climate, such as Le Roy Ladurie's "human and comparative history of the climate." But the approach also suits broader agendas. Broodbank structured the tabular synopsis of his magnificent Making of the Middle Sea in terms of climate phases from 2 million B.P. to 500 B.C. Climate phases head two of his first three chronological tables, and 
climate shifts set the pace for chapters 3 and 4. Similarly, Harper's recent assessment of the fall of the Roman Empire not only lends a prominent place to environmental change but also features a timeline in which simplified Roman climate history tops the graphic overview. Some scholars have gone even farther in fusing climate change with more traditional political periodizationfor instance, by linking explicitly the dynastic changes that scan China's history with cooling periods. $^{28}$

A fourth trend discloses itself as a sign of a maturing transdisciplinary impulse. The most recent work makes room for informed exploitation of paleoclimate science. Nonetheless, it generally eschews a deterministic view of the interaction between climate change and human civilization, whether the theme is the end of the medieval economy, uprising in Ottoman Anatolia, European colonization of North America, or the global history of the seventeenth century. More positively formulated, this trend emphasizes the role of societal resilience in the face of environmental change. Already in 1980, de Vries delved into quantifying human responses that limited the economic impact of early modern short-term climate variation. A more recent argument is that shipping systematically buffered the Roman economy from the droughts to which the Mediterranean was prone, creating a virtual "water trade" by moving food production from well-watered zones to more arid ones. A similar argument about the medieval movement of preserved fish from the North Sea and Baltic into other areas of Europe appears apropos. At least since Pettersson's early work, studies about the rise of the of herring and cod industries, not least those of the Hanseatic League cities, have tended to include mentions of the environmentally driven migrations of these fish. Nevertheless, careful archaeological investigation underscores the resilient social response to climate, revealing that technological advances and shifts in the historical infrastructure of supply and demand can trump raw climate 
change and the migration trajectories of spawning grounds in the earliest rise of the North Sea herring industry. ${ }^{29}$

Like the incipient debate about the Siberian High and medieval cotton production, this fourth trend also insists on a critical and measured approach in weighing the potential impact of weather events against other factors. For example, the study of fossilized pollens has led to a modulated appraisal of the part that changes in precipitation played in the changing rural economies of late antique Anatolia. Similarly informed and critical discussion has centered on the role of climate events in the withdrawal of Mongols from their invasion of thirteenth-century Hungary. ${ }^{30}$

Climate and Disease That critical approach entails recognition of when the appeal to climatic causes appears plausible but still imperfectly resolved. The perennial question of how climate change connects with disease regimes attracted a certain skepticism in 1980. Recently the search for climate triggers of major disease outbreaks, especially in antiquity, has intensified as scholars, sometimes begrudgingly, start to recognize their profound consequences. Conditions favoring Yersinia pestis and the bubonic plague in the Justinianic Pandemic (541-c. 750) and the Black Death and Second Pandemic (1347-1772) have been of particular interest. Epidemiologists and historians have long noted the temperature and humidity that favor or hinder the rodent hosts and insect vectors of plague, and they continue to seek the specific environmental conditions that could have precipitated, sustained, or ended specific outbreaks or the broader sequences of outbreaks that continued for centuries..$^{31}$

Leaving aside such general conditions as the frailty of human populations as a result of earlier nutrition crises inflicted by climate or other disruptions, some epidemiological and epizootic patterns seem to shed indirect light on the specific conditions leading to outbreaks of 
plague. For example, more precipitation often allows a trophic cascade, that is, increased food availability up and down the food chain of disease hosts, fostering a population explosion that ultimately stresses a host population as resources fail to keep up with demand, and opens the stressed host population to disease crises. More intricate scenarios have also been advanced—for instance, a sequence of precipitation-induced trophic cascades followed by drought and concomitant stress, as observed among North American hosts of endemic plague. Yet, however much a general connection between changing climate patterns and epidemic disease seems plausible, the details of the complex potential climate/host/vector mechanisms have so far escaped unambiguous identification and resolution. ${ }^{32}$

Climate and Settlement Patterns Climate data also promise sharp new insights about the long-term shifts in settlement patterns that are essential to understanding land use and economic organization. Unexplained movements in settlement locations to higher or lower places could well be a fruitful area of environmental archaeological investigation. Could some of these movements be connected with recently identified multidecadal shifts in precipitation that affect water tables? As precipitation declined, for instance, dropping sub-surface water tables will have made wells run dry, forcing settlements either to dig deeper wells or to move downhill to reach the new water table. Conversely, periods of increased precipitation could have encouraged settlements to move upward, away from excessively wet sites. Just such a scenario arose in late medieval Hungary. A quantitative evaluation of archaeologically detected lowland settlement patterns over 600 years shows that during the drier and warmer Medieval Climate Anomaly, settlements were situated significantly lower than during the wetter and cooler late Middle Ages (c. 1250-1550) and the changed conditions of the Little Ice Age. 
The sudden onset of moister conditions in the thirteenth century led to permanent structural transformations in settlement patterns and the rural economy embedded in them, not to mention massive internal migration. Ultimately, the region's rich flood-fed grass promoted fifteenth-century Hungary into a major supplier of cattle to Europe. As this example and so many others suggest, the expanding integration of science into the study of the human past is forging a broad new discipline that deepens and sometimes disrupts our established historical wisdom. ${ }^{33}$

The Future of Archaeoscience The course of the future is unmistakable. Multiple investigators with diverse competences in climate science, history, and archaeology must continue to collaborate. Just as no lone archaeologist would seriously contemplate excavating even a small site, so must historians engage in teamwork to exploit the promise of the new methods to their fullest extent. Our traditional historical sources gain new life in dialogue with new data and new questions.

(One academic red herring is worth mentioning in this regard. Historians sometimes worry that multiple authorship will compromise young scholars' promotion: How will committees know who wrote what in multi-authored studies? This is a false dilemma. Everyday great universities grant tenure to brilliant individual scientists who have never published a single paper alone, and the Nobel Prize committees have no trouble understanding the rules governing the hierarchy of contributors to the articles in most of the major peer-reviewed publications.)

The most fruitful collaborations do not arise ex post facto. Scientists do not approach historians only when they encounter problems that they cannot solve themselves, and historians do not approach climate scientists with questions only after the collection and analysis of data 
are done. As in archaeology, so in archaeoscience: The most productive collaborations begin as early as possible, in the conception, birth, and execution of a project.

It is easier to exploit proxy evidence in which the basic features, such as nature, chronology, significance, and robustness of the signals, are already well established, but inquiry is far more fruitful when historians, archaeologists, and scientists come together before the evidence is collected to formulate questions and strategies. My own research has progressed from an initial use of existing measurements from the Greenland ice core produced by Paul Mayewski's team during the 1990s in the GISP2 expedition to an active participation in the more recent innovative and ongoing work of the Historical Ice Core Project, which Mayewski, Dietmar Wagenbach, and I conceived in 2013. The Project includes all manner of fact finding, from the retrieval and measurement of chemical species to the comparison of data with the historical and archaeological records. Benefiting from our European colleagues' expertise on the Swiss glacier, we enlisted CCI's scientists, with their state-of-the-art technology, and Harvard University's community of historians, archaeologists, and scientists. Our team's members range from the most senior professors to undergraduates and other interested parties. ${ }^{34}$

A key element in the birthing of such an integrative enterprise is that the climate scientists, historians, and archaeologists involved learn to speak each other's "language" and to appraise the strengths and weaknesses of methods, instruments, and data that may never have been part of their toolkits before. Today’s scientific historical revolution demands that young researchers be exposed to new disciplinary frontiers. Humanists and scientists alike, whatever their professional status, usually welcome with open arms the opportunity to contribute directly to the creation of new scientific and historical knowledge. 
Technological advances, such as CCI's LA-ICP-MS and next-generation sequencing in archaeogenetics, are producing amazing new evidence. But establishing new transdisciplinary investigations requires more than technology, will, and resources; it also requires new platforms that can unite humanists and scientists for the long haul. Archaeology departments and institutes around the world have been developing them more or less on an ad hoc basis for some time: the programs at the University of Oxford's venerable Research Laboratory for Archaeology and the History of Art (1955), the University of Cambridge's McDonald Institute for Archaeological Research (1990), the Weizmann Institute's Kimmel Center for Archaeological Science at (1997), the University of Arizona's program in archaeological sciences (2002), Arizona State University's School of Human Evolution and Social Change (2005), and the Max Planck Institute for the Science of Human History (2014), to name just some which are active in historical periods. Less expensive but high-performing nonetheless are the research networks that ensure continuous interaction, collective programs, and close cooperation within universities between different individuals, research groups, and laboratories, such as Harvard University’s Initiative for the Science of the Human Past (2011). Innovative programs combine existing institutions and networks with complementary strengths in coordinated research programs and university education. Thanks to the low cost of digital conferencing and communications, they can even bridge oceans, as does the new Max Planck-Harvard Research Center for the Archaeoscience of the Ancient Mediterranean (https://www.archaeoscience.org/). The interdisciplinary investigation of ancient climates has found a place in most of these new platforms. 
The new scientific climate history is about more than just the history of climate. As noted at the outset, the new history of climate is developing in a new climate of history; it forms one of several leading edges in archaeoscience, the broader transdisciplinary convergence that brings the power of science to bear on the human past. Along with the emergence of archaeogenetics, molecular archaeology, and digital humanities—such as geographical information systems (GIS) and computational philology (quantitative studies of textual authorship) — climate history is in the process of achieving the long-imagined re-unification of the sciences and the humanities as it unveils historical changes in the environment. In this great venture, the Journal of Interdisciplinary History will continue to play a signal role. 
Footnotes

${ }^{1}$ David Reich, Who We Are and How We Got Here: Ancient DNA and the New Science of the Human Past (New York, 2018); Christina Warinner, Alexander Herbig, et al., “A Robust Framework for Microbial Archaeology," Annual Review of Genomics and Human Genetics, XVIII (2017), 321-356.

${ }^{2}$ For recent work about climate and history in this journal, see Morgan Kelly and Cormac Ó Gráda, “The Waning of the Little Ice Age: Climate Change in Early Modern Europe,” Journal of Interdisciplinary History, XLIV (2013), 301-325; Sam White, “The Real Little Ice Age,” ibid., 327-352; Ulf Büntgen and Lena Hellmann, “The Little Ice Age in Scientific Perspective: Cold Spells and Caveats," ibid., 353-368; Jan de Vries, "The Crisis of the Seventeenth Century: The Little Ice Age and the Mystery of the 'Great Divergence,'” ibid., 369-377; John Haldon, Neil Roberts et al., "The Climate and Environment of Byzantine Anatolia: Integrating Science, History, and Archaeology," ibid., XLV (2014), 113-161; Kelly and Ó Gráda, "Debating the Little Ice Age,” ibid., 57-68; Dagomar Degroot, “Testing the Limits of Climate History: The Quest for a Northeast Passage during the Little Ice Age, 1594-1597,’ ibid. (2015), 459-484; Kyle Harper, "Civilization, Climate and Malthus: The Rough Course of Global History,” ibid., 549-566; Hui-wen Koo, "Weather, Harvests, and Taxes: A Chinese Revolt in Colonial Taiwan," ibid., XLVI (2016), 39-59; Enric Tello, José Luis Martínez, et al., “The Onset of the English Agricultural Revolution: Climate Factors and Soil Nutrients,” ibid., XLVII (2017), 445-474; John L. Brooke, "Malthus and the North Atlantic Oscillation: A Reply to Kyle Harper,” ibid., 563-578; Harper, “A Reply to John L. Brooke's 'Malthus and the North Atlantic Oscillation,"” ibid., 579-584; Timothy P. Newfield and Inga Labuhn, "Realizing Consilience in Studies of PreInstrumental Climate and Pre-Laboratory Disease,” ibid., XLVIII (2017), 211-240; Nicola Di 
Cosmo, Amy Hessl, et al., "Environmental Stress and Steppe Nomads: Rethinking the History of the Uyghur Empire (744-840) with Paleoclimate Data," ibid., XLVIII (2018), 439-463; ShortTerm Climatic Catastrophes and the Collapse of the Liao Dynasty (907-1125): Yali Li, Gideon Shelach-Lavi, and Ronnie Ellenblum, "Short-Term Climatic Catastrophes and the Collapse of the Liao Dynasty (907-1125): Textual Evidence, ”ibid., XLIX (2019), 591-610.

${ }^{3}$ For an American pioneer in climate study, see Ellsworth Huntington, The Pulse of Asia: A Journey in Central Asia Illustrating the Geographic Basis of History (Boston, 1907); idem, "Climatic Change and Agricultural Exhaustion as Elements in the Fall of Rome," Quarterly Journal of Economics, XXXI (1917), 173-208, repr. in Mortimer Chambers (ed.), The Fall of Rome: Can It Be Explained? (New York, 1963), 55-61. For Huntington’s intellectual trajectory, including his involvement with the eugenics movement, see Keay Davidson, "Huntington, Ellsworth (1876-1947), Explorer and Geographer," in Susan Ware (ed.), American National Biography Online (New York, 1999), available at http://www.anb.org/ (accessed June 18, 2018). For a European pioneer, see Otto Pettersson (1848-1941), whose Climatic Variations in Historic and Prehistoric Time (Berlin, 1914), 1-27, treats medieval Iceland and Greenland (7-10); medieval storm floods (15-17); and ocean circulation, freezing seas, and herring fisheries (2023). See also Artur Svansson, “Otto Pettersson,” in Göran Nilzén (ed.), Svenskt biografiskt leksikon (Stockholm, 1995-1997), 261-269. Historians of science will know other early explorers of history and climate who go unmentioned herein.

See Hubert H. Lamb, review of Rhys Carpenter, Discontinuity in Greek Civilization, Antiquity, XLI (1966), 234. About the conference in Boulder, see Reid A. Bryson and Christine Padoch, "On the Climates of History," in the special issue, "History and Climate," Journal of Interdisciplinary History, X (1980), 584-585 (other citations from this memorable issue are 
scattered throughout these notes). Carpenter, Discontinuity in Greek Civilisation (Cambridge, 1966). For the view that climate was stable and humans caused environmental change, see, Rhoads Murphey, “The Decline of North Africa since the Roman Occupation: Climatic or Human?” Annals of the Association of American Geographers, XLI (1951), 116-132.

${ }^{4}$ For a thoughtful use of historical evidence, see Lamb, “The Early Medieval Warm Epoch and Its Sequel,” Palaeogeography, Palaeoclimatology, Palaeoecology, I (1965), 13-37; for the early medieval warm period, see also idem, Climate, History and the Modern World (New York, 1995; orig. pub. 1982). Fernand Braudel, La Méditerranée et le monde méditerranéen à l'époque de Philippe II (Paris, 1949); idem, The Mediterranean and the Mediterranean World in the Age of Philip II (New York, 1972), I, 25-352. Emmanuel Le Roy Ladurie, “Histoire et climat,” Annales: économies, sociétés, civilisations, 14 (1959), 3-34; idem, Histoire du climat depuis l'an mil (Paris, 1967); idem, Times of Feast, Times of Famine: A History of Climate since the Year 1000 (New York, 1971). See also the review of the English translation by John D. Post, “Meteorological Historiography,” Journal of Interdisciplinary History, III (1973), 721-732; Isabelle Chuine, Pascal Yiou, et al., "Grape Harvest Dates and Temperature Variations in Eastern France since 1370,” Nature, CDXXXII (2004), 289-290; Le Roy Ladurie, Daniel Rousseau et al., Les fluctuations du climat de l'an mil à nos jours (Paris, 2011). Christian Pfister, Agrarkonjunktur und Witterungsverlauf im westlichen Schweizer Mittelland, 1755-1797 (Bern, 1975); idem, Das Klima der Schweiz von 1525-1860 und seine Bedeutung in der Geschichte von Bevölkerung und Landwirtschaft (Bern, 1984); Pierre Alexandre, Le climat au Moyen Âge en Belgique et dans les régions voisines (Rhénanie, Nord de la France) (Louvain, 1976); idem, Le climat en Europe au Moyen Âge: contribution à l'histoire des variations climatiques de 1000 à 1425, d'après les sources narratives de l'Europe occidentale (Paris, 1987); Pfister, "Climate and 
Economy in Eighteenth-Century Switzerland," Journal of Interdisciplinary History, IX (1978), 223-243; Rudolf Brázdil, Pfister, et al., "Historical Climatology In Europe - the State of the Art,” Climatic Change, LXX (2005), 363-430. Ka-Wai Fan, “Climatic Change and Dynastic Cycles in Chinese History: A Review Essay,” WIRES Climate Change, VI (2010), 225-226.

${ }^{5}$ Le Roy Ladurie and Micheline Baulant, "Grape Harvests from the Fifteenth through the Nineteenth Centuries," in the special issue, "History and Climate," 839-849; Stothers, "Mystery Cloud of AD 536," Nature, CCCVII (1984), 344-345; Michael Sigl, Mai Winstrup, et al., “Timing and Climate Forcing of Volcanic Eruptions for the Past 2,500 Years," ibid., 523 (2015), 543-549. That volcano has just been identified in Iceland from tephra discovered in the Historical Ice Core Project (see below). This new informationshould allow more precise and detailed reconstruction of its climatic impact: Christopher P. Loveluck, M. McCormick, N. E. Spaulding, H. Clifford, M. J. Handley, L. Hartman, H. Hoffmann, E. V. Korotkikh, A. V. Kurbatov, A. F. More, S. B. Sneed, and P. A. Mayewski. "Alpine ice-core evidence for the transformation of the European monetary system, AD 640-670." Antiquity XCII (2018), 15711585.

${ }^{6}$ See this journal's special issue, "History and Climate," 583-861. John A. Eddy, "Climate and the Role of the Sun," Journal of Interdisciplinary History, X (1980), 725-747; Thompson Webb, “The Reconstruction of Climatic Sequences from Botanical Data,” ibid., 749-772; Harold C. Fritts, G. Robert Lofgren, et al., "Past Climate Reconstructed from Tree Rings," ibid., 773-793. Alexander T. Wilson, "Isotope Evidence for Past Climatic and Environmental Change," ibid., 795-812. For a detailed survey of the main types of proxy evidence from nature, see Raymond S. Bradley, Paleoclimatology: Reconstructing Climates of the Quaternary (Amsterdam, 2014; orig. pub. 1985), 137-516. 
${ }^{7}$ Andrew E. Douglass, Climatic Cycles and Tree-Growth (Washington, D.C., 1919-1936). For an overview of tree-ring work, see Bradley, Paleoclimatology, 452-499; for eastern Mediterranean projects, Cornell's Laboratory for Aegean and Near Eastern Dendrochronology, available at https://dendro.cornell.edu/ and Arizona's Aegean Dendrochronology Project, available at http://ltrr.arizona.edu/aegean. Büntgen, Willy Tegel, et al., "2500 Years of European Climate Variability and Human Susceptibility,” Science, CCCI (2011), 578-582; Jürg Luterbacher, Johannes P. Werner, et al., "European Summer Temperatures since Roman Times," Environmental Research Letters, XI (2016), 024001; Edward R. Cook, North American Drought Atlas: A History of Meteorological Drought Reconstructed from 835 Tree-Ring Chronologies for the Past 2005 Years, available at https://iridl.1deo.columbia.edu/SOURCES/.LDEO/.TRL/.NADA2004/.pdsi-atlas.html; idem, Old World Drought Atlas, available at https://www.ncdc.noaa.gov/paleo-search/study/19419; idem, Richard Seager, et al., "Old World Megadroughts and Pluvials during the Common Era," Science Advances, I (2015), e1500561.

${ }^{8}$ For an overview of some of the key historical paleoclimate parameters from ice cores, see McCormick, Büntgen, et al., "Climate Change during and after the Roman Empire and Its Successors: Reconstructing the Past from Scientific and Historical Evidence," Journal of Interdisciplinary History, XLIII (2012), 209-210.

${ }^{9}$ Sharon B. Sneed, Paul A. Mayewski, et al., "Instruments and Methods: New LA-ICP-MS Cryocell and Calibration Technique for Sub-Millimeter Analysis of Ice Cores,” Journal of Glaciology, LXI (2015), 233-242.

${ }^{10}$ Bradley, Paleoclimatology; McCormick, Büntgen et al., "Climate Change during and after the Roman Empire," 212-213, 216-217. The “European Pollen Database," available at 
http://www.europeanpollendatabase.net/, offers easy access to fossilized pollen records collected around Europe. Hilmar A. Holland, Bernd R. Schöne, et al., "Decadal Climate Variability of the North Sea during the Last Millennium Reconstructed from Bivalve Shells (Arctica islandica)," The Holocene, XXIV (2014), 771-786; Paul G. Butler, Alan D. Wanamaker, Jr., et al., "Variability of Marine Climate on the North Icelandic Shelf in a 1357-Year Proxy Archive Based on Growth Increments in the Bivalve Arctica islandica," Palaeogeography, Palaeoclimatology, Palaeoecology, CCCLXXIII (2013), 141-151.

11 For CCI's Climate Re-Analyzer ${ }^{\mathrm{TM}}$, see http://cci-reanalyzer.org/.

${ }^{12}$ Richard Hennig, Katalog bemerkenswerter Witterungsereignisse von den ältesten Zeiten bis zum Jahre 1800 (Berlin, 1904); Curt Weikinn and Michael Börngen, Quellentexte zur Witterungsgeschichte Europas von der Zeitwende bis zum Jahre 1850 (Berlin, 1958-2002), 6 v.; Alexandre, Le climat en Europe au Moyen Âge (the geographical classifications and source references are not always easy to manipulate); Jan Buisman and Aryan F. V. van Engelen, Duizend jaar weer, wind en water in de Lage Landen (Franeker, 1995-), 6 v.; Ioannes G. Telelēs,

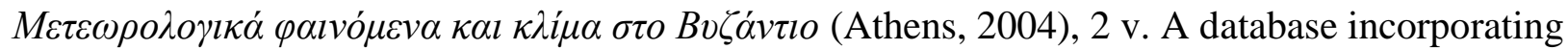
the famine-related materials in Alexandre's works (n. 4) is presently under construction: JeanPierre Devroey and Alexis Wilkin, FAMe: Famines in Antiquity and the Middle Ages: An Electronic Database, available at http://fame.otlet-institute.org/. See also n. 14.

${ }^{13}$ Euro-Climhist Database, available at http://www.euroclimhist.unibe.ch/; Pfister, "Historical Weather Indices from Switzerland," the NOAA National Centers for Environmental Information, available at https://www.ncdc.noaa.gov/paleo-search/study/5411; Valérie Daux, Iñaki Garcia de Cortazar-Atauri, et al., “An Open-Access Database of Grape Harvest Dates for Climate Research: Data Description and Quality Assessment," Climate of the Past, VIII (2012), 1403- 
1418, available for download at https://www.ncdc.noaa.gov/paleo-search/study/13194. See as a data set in either pdf or csv format, Steffen Vogt, Rüdiger Glaser, et al., "The Grotzfeld Data Set - Coded Environmental, Climatological and Societal data for the Near and Middle East from AD 801 to 1821," (2016), available at https://d-nb.info/1124005161/34; for the data set, doi: 10.6094/tambora.org/2016/c156/data.zip.

${ }^{14}$ See McCormick, Eurydice Georganteli, et al. (eds.), Digital Atlas of Roman and Medieval Civilizations [DARMC], Version 1.3.1 (2014), "Data Availability," available at https://darmc.harvard.edu/data-availability. The conditions of use are as liberal as possible: "This work is licensed under a Creative Commons Attribution-NonCommercial-ShareAlike 4.0 International License. In the context of the DARMC project, this means that you are free to take and build upon our work in your own scholarship, as long as you acknowledge DARMC and the original content creators as the source of the data. You are free to remix and rehost this data, and to release derived products. DARMC is committed to making spatial-historical data freely available to the academic community; under no circumstances may you charge money for access to this data."

${ }^{15}$ Lamb, "Early Medieval Warm Epoch," 20-22, lays out his solution of numerical indices. For a thorough description of the process applied in the Grotzfeld Middle Eastern data set, see Vogt, Glaser, et al., "Grotzfeld data set," 7-8; for various quantification procedures developed in the exploitation of Chinese historical records, Jiacheng Zhang and Thomas J. Crowley, "Historical Climate Records in China and Reconstruction of Past Climates," Journal of Climate, II (1989), 839-841; for an example of more complex quantification into thermal and precipitation indices, Pfister, "The Little Ice Age: Thermal and Wetness Indices for Central Europe,” in the special issue, "History and Climate," 665-696. Nick Patterson, “Appendix: A Statistical Analysis," in 
McCormick, Paul Edward Dutton, et al., "Volcanoes and the Climate Forcing of Carolingian Europe, A.D. 750-950,” Speculum, LXXXII (2007), 894-895; Zsolt Pinke, László Ferenczi, et al., "Zonal Assessment of Environmental Driven Settlement Abandonment in the Trans-Tisza Region (Central Europe) during the Early Phase of the Little Ice Age," Quaternary Science Reviews, CLVII (2017), 106 (Figure 5).

${ }^{16}$ Büntgen, Tegel, et al., "2500 Years of European Climate Variability.” The two exceptions in the sources were among the mostly poorly documented years, each having only one report of uncertain relevance.

${ }^{17}$ Edward O. Wilson, Consilience: The Unity of Knowledge (New York, 1998); McCormick, “History's Changing Climate: Climate Science, Genomics and the Emerging Consilient Approach to Interdisciplinary History,” Journal of Interdisciplinary History, XLII (2011), 252273.

${ }^{18}$ For an effective statement about the use of written records to reinforce scientific results, see the prize-winning undergraduate research of Matthew T. Luongo, "Comparison and Calibration of Climate Proxy Data in Medieval Europe," as-yet unpub. senior thesis (Harvard Univ., 2017). ${ }^{19}$ Alexander F. More, Nicole E. Spaulding et al., "Next Generation Ice Core Technology Reveals True Minimum Natural Levels of Lead $(\mathrm{Pb})$ in the Atmosphere: Insights from the Black Death," GeoHealth, I (2017), 214-216; idem et al., "The Role of Historical Context in Understanding Past Climate, Pollution and Health Data in Trans-Disciplinary Studies,” GeoHealth, II (2018), 162-170.

${ }^{20}$ Peter Spufford, Money and Its Use In Medieval Europe (New York, 1988), maintained that new mines repeatedly played a key role in medieval monetary and economic innovations; he wondered about the potential of Melle in this regard (32-33), even though its archaeology was 
then unknown. Philip Grierson and Mark Blackburn, Medieval European Coinage (New York, 1986), I, 96-97, thought instead that the silver came from recycling confiscated silver objects. Florian Téreygeol, "Y-a-t-il un lien entre la mise en exploitation des mines d'argent de Melle (Deux-Sèvres) et le passage au monométallisme argent vers 675?” in Luc Bourgeois (ed.), Wisigoths et francs autour de la bataille de Vouillé, 507 (Saint-Germain-en-Laye, 2010), 251261, reconstructed the history of Melle from archaeological and numismatic studies, concluding from the evidence then available that the Melle discovery did not suddenly cause the shift to silver coinage. This contention may be true as formulated, but the new ice-core evidence compellingly indicates that the major new source of silver weighed heavily in the decision to switch to the new precious metal for the coin of the realm. See Christopher P. Loveluck, McCormick, et al., "Ice Evidence for Transformation of the European Monetary System, AD 640-670: Preliminary Insights from an Alpine Ice Core,” Antiquity (in press). Joseph R. McConnell, Andrew I. Wilson, et al., "Lead Pollution Recorded in Greenland Ice Indicates European Emissions Tracked Plagues, Wars, and Imperial Expansion during Antiquity,” Proceedings of the National Academy of Sciences CXV (2018) 5726-5731\#\#\#.

${ }^{21}$ Harvey Weiss, M.-A. Courty, et al., “The Genesis and Collapse of Third Millennium North Mesopotamian Civilization,” Science, CCLXI (1993), 995-1004. For the differing responses now evident at three neighboring sites, see Jason Ur, "Urban Adaptations to Climate Change in Northern Mesopotamia," in Pernille Bangsgaard, Rachel J. Dann, et al. (eds.), Climate and Ancient Societies (Copenhagen, 2015), 69-96. The literature linking climate to the collapse of civilizations is now substantial. See, for example, Malcolm H. Wiener, "The Interaction of Climate Change and Agency in the Collapse of Civilizations ca. 2300-2000 BC," Radiocarbon, LVI (2014), S1-S16; for the regions mentioned, Antonio Blanco-González, Katina T. Lillios, et 
al., "Cultural, Demographic and Environmental Dynamics of the Copper and Early Bronze Age in Iberia (3300-1500 BC): Towards an Interregional Multiproxy Comparison at the Time of the 4.2 ky BP Event," Journal of World Prehistory, XXXI (2018), 1-79; Chun Chang Huang, Jiangli Pang, et al., "Extraordinary Floods Related to the Climatic Event at $4200 \mathrm{ka} \mathrm{BP}$ on the Qishuihe River, Middle Reaches of the Yellow River, China," Quaternary Science Reviews, XXX (2011), 460-468 (with further references); Michael Staubwasser, Frank Sirocko, et al., "Climate Change at the $4.2 \mathrm{ka}$ BP Termination of the Indus Valley Civilization and Holocene South Asian Monsoon Variability," Geophysical Research Letters, XXX (2003), 7-1 to 7-4.

${ }^{22}$ David A. Hodell, Jason H. Curtis, et al., "Possible Role of Climate in the Collapse of Classic Maya Civilization," Nature, CCCLXXVI (1995), 391-394. For the history of the debate about the collapse of the Maya civilization, see Norman Hammond, "Climate, Crisis, Collapse, and Ancient Maya Civilization: An Enduring Debate," in A. Bruce Mainwaring, Robert Giegengack, et al. (eds.), Climate Crises in Human History (Philadelphia, 2010), 189-196. Burghart Schmidt and Wolfgang Gruhle, "Klimaextreme in römischer Zeit: Eine Strukturanalyse dendrochronologischer Daten,” Archäologisches Korrespondenzblatt, XXXIII (2003), 421-426; idem et al., "Globales Auftreten ähnlicher Wuchsmeister von Bäumen--Homogenitätsanalyse als neues Verfahren für die Dendrochronologie und Klimaforschung," Germania, LXXXXIV (2006), 431-465; idem et al., "Klimaextreme in bandkeramischer Zeit (5300 bis 5000 v. Chr.): Interpretation Dendrochronologischer und Archäologischer Befunde,” Archäologisches Korrespondenzblatt, XXXIV (2004), 303-307; idem et al., "Mögliche Schwankungen von Getreideerträgen—Befunde zur rheinischen Linienbandkeramik und römischen Kaiserzeit,” ibid., XXXV (2005), 301-316. I am personally grateful to Burghart Schmidt for helping me to 
understand the power of dendrodata for economic history, as well as to Thomas Fischer and Joachim Henning for introducing me to him in 2005.

${ }^{23}$ The October 2005 workshop owes its thanks to the funding provided by a Distinguished Achievement Award from the Andrew W. Mellon Foundation. In addition to Fischer, Henning, and Schmidt, the participants were Paul Dutton (History, Simon Fraser University), Yizhar Hirschfeld (Archaeology, Hebrew University), Thomas Litt (Palaeontology, University of Bonn), Mayewski (CCI, University of Maine), Michael B. McElroy (Earth and Planetary Sciences, Harvard University), John Raymond (Harvard-Smithsonian Center for Astrophysics), Noreen Tuross (Anthropology, Harvard), and Eli Tziperman (Earth and Planetary Sciences, Harvard). Kyle Harper and Dorian S. Abbot, the two graduate-student scribes at the time, now have accomplished academic careers.

McCormick, Dutton, et al., "Volcanoes and the Climate Forcing of Carolingian Europe." Around the same time, the thoughtful study of Benoît Rossignol and Sébastien Durost"Volcanisme global et variations climatiques de courte durée dans l'histoire romaine (I ${ }^{\mathrm{er}} \mathrm{s}$. av. J.C.- IV ${ }^{\mathrm{ème}}$ s. ap. J.-C.): leçons d'une archive glaciaire (GISP2),” Jahrbuch des römischgermanischen Zentralmuseums Mainz, LIV (2007), 395-438 - proposed links between volcanic signals in GISP2 and a series of events in Roman history. Wolfgang Behringer, Kulturgeschichte des Klimas: von der Eiszeit bis zur globalen Erwärmung (Munich, 2006); idem, Hartmut Lehmann, et al. (eds.), Kulturelle Konsequenzen der "Kleinen Eiszeit” (Göttingen, 2005). ${ }^{24}$ Elena Xoplaki, Dominik Fleitmann, et al. (eds.), "Medieval Climate Anomaly," Pages News, XIX (2011), 1-39; McCormick, Büntgen, et al., "Climate Change during and after the Roman Empire," updated by Harper and McCormick as "Reconstructing the Roman Climate," in Walter Scheidel (ed.), The Science of Roman History: Biology, Climate, and the Future of the Past 
(Princeton, 2018), 11-52. See also the relevant chapters in William V. Harris (ed.), The Ancient Mediterranean Environment between Science and History (Leiden, 2013). Haldon, Roberts, et al., "The Climate and Environment of Byzantine Anatolia"; Karin Holmgren, Alexandra Gogou, et al., "Mediterranean Holocene Climate, Environment and Human Societies," Quaternary Science Reviews, CXXXVI (2016), 1-4, introducing studies of France, Albania, Sicily, Greece, and Anatolia and the Levant. Among them are Adam Izdebski, Jordan Pickett, et al., "The Environmental, Archaeological and Historical Evidence for Regional Climatic Changes and Their Societal Impacts in the Eastern Mediterranean in Late Antiquity," ibid., 189-208. They develop a chronology that differs considerably from that proposed by McCormick, Büntgen et al., "Climate Change during and after the Roman Empire," for what they contend were late antique drought and wet periods common to Anatolia and the Levant. More and better proxy evidence will be needed to resolve this important question. Xoplaki, Fleitmann et al., "The Medieval Climate Anomaly and Byzantium: A Review of the Evidence on Climatic Fluctuations, Economic Performance and Societal Change," ibid., 229-252, offer a valuable synthesis for the northeastern Mediterranean region.

${ }^{25}$ Büntgen, Vladimir S. Myglan, et al., "Cooling and Societal Change during the Late Antique Little Ice Age from 536 to around 660 AD,” Nature Geoscience, IX (2016), 231-236.

${ }^{26}$ Richard W. Bulliet, Cotton, Climate, and Camels in Early Islamic Iran: A Moment in World History (New York, 2009); Deborah G. Tor, “The Eclipse of Khurāsān in the Twelfth Century,” Bulletin of the School of Oriental and African Studies, LXXXI (2018), 1-26; Ellenblum, The Collapse of the Eastern Mediterranean: Climate Change and the Decline of the East, 950-1072 (New York, 2012). See Sam White's judicious appraisal in his review of Ellenblum's book in Mediterranean Historical Review, XXVIII (2013), 70-72. 
${ }^{27}$ Brian M. Fagan, The Long Summer: How Climate Changed Civilization (New York, 2004); idem, The Great Warming: Climate Change and The Rise and Fall of Civilizations (New York, 2008). The scientific information in these two works is now dated. Brooke, Climate Change and the Course of Global History: A Rough Journey (New York, 2014). See Harper's review essay on Brooke's book, "Civilization, Climate and Malthus," and the ensuing dialogue between Harper and Brooke in this journal—Brooke, "Malthus and the North Atlantic Oscillation: A Reply to Kyle Harper”; Harper, “A Reply to John L. Brooke’s 'Malthus and the North Atlantic Oscillation."”

${ }^{28}$ Le Roy Ladurie, Histoire humaine et comparée du climat (Paris, 2004), 2 v. For the tables, see Cyprian Broodbank, Making of the Middle Sea: A History of the Mediterranean from the Beginning to the Emergence of the Classical World (New York, 2013), 10-13. The titles of Chapters 3 and 4 are "The Speciating Sea (1.8 Million To 50,000 Years Ago)" and "A Cold Coming We Had of It (50,000-10,000 BC)” (Pleistocene climate, 88-91). Harper, The Fate of Rome: Climate, Disease, and the End of an Empire (Princeton, 2017), xii-xiii; David D. Zhang, Chi Yung Jim, et al., "Climatic Change, Wars and Dynastic Cycles in China over the Last Millennium," Climatic Change, LXXVI (2006), 459-477.

${ }^{29}$ Bruce M. S. Campbell, The Great Transition: Climate, Disease and Society in the Late Medieval World (New York, 2016); White, The Climate of Rebellion in the Early Modern Ottoman Empire (New York, 2011); idem, A Cold Welcome: The Little Ice Age and Europe's Encounter with North America (Cambridge, Mass., 2017); Geoffrey Parker, Global Crisis: War, Climate Change and Catastrophe in the Seventeenth Century (New Haven, 2013); de Vries, "Measuring the Impact of Climate on History: The Search for Appropriate Methodologies," in the special issue, "History and Climate," 599-630. For the "water trade," see, for example, Brian 
J. Dermody, R. P. H. van Beek, et al., "A Virtual Water Network of the Roman World," Hydrology and Earth Systems Science, XVIII (2014), 5025-5040. Pettersson, Climatic Variations in Historic and Prehistoric Time. For the climate and biological factors affecting the cycles of the Bohuslen fishery, see Carsten Jahnke, Das Silber des Meeres: Fang und Vertrieb von Ostseehering zwischen Norwegen und Italien (12.-16. Jahrhundert) (Cologne, 2000), 282-283.

James H. Barrett, Alison M. Locker, et al., "The Origins of Intensive Marine Fishing in Medieval Europe: The English Evidence," Proceedings of the Royal Society: Biological Sciences, CCLXXI (2004), 2417-2421; idem et al., “'Dark Age Economics’ Revisited: The English Fish Bone Evidence AD 600-1600,” Antiquity, LXXVIII (2004), 618-636; Barrett, Cluny Johnstone, et al., "Detecting the Medieval Cod Trade: A New Method and First Results," Journal of Archaeological Science, XXXV (2008), 850-861.

${ }^{30}$ Izdebski, "Why Did Agriculture Flourish in the Late Antique East? The Role of Climate Fluctuations in the Development and Contraction of Agriculture in Asia Minor and the Middle East from the 4th till the 7th c. AD," Millennium. Jahrbuch zu Kultur und Geschichte des ersten Jahrtausends n. Chr., VIII (2011), 291-312; idem, A Rural Economy in Transition: Asia Minor from Late Antiquity into the Early Middle Ages (Warsaw, 2013); Büntgen and Di Cosmo, "Climatic and Environmental Aspects of the Mongol Withdrawal from Hungary in 1242 CE," Scientific Reports, VI (2016), 25606; Zsolt Pinke, László Ferenczi, et al., "Climate of Doubt: A Re-Evaluation of Büntgen and Di Cosmo’s Environmental Hypothesis for the Mongol Withdrawal from Hungary, 1242 CE,” ibid., VII (2017), 12695.

${ }^{31}$ Andrew B. Appleby, "Epidemics and Famine in the Little Ice Age," in the special issue, “History and Climate," 643-663; McCormick, “Tracking Mass Death during the Fall of Rome's Empire (I),” Journal of Roman Archaeology, XXVIII (2015), 326-328. 
${ }^{32}$ Lei Xu, Leif C. Stige, et al., "Wet Climate and Transportation Routes Accelerate Spread of Human Plague," Proceedings of the Royal Society of London B: Biological Sciences, CCLXXXI (2014), 20133159; Robert R. Parmenter, Ekta P. Yadav, et al., "Incidence of Plague Associated with Increased Winter-Spring Precipitation in New Mexico," American Journal of Tropical Medicine and Hygiene, LXI (1999), 814-821; Boris V. Schmid, Büntgen, et al., "Climate-Driven Introduction of the Black Death and Successive Plague Reintroductions into Europe,” Proceedings of the National Academy of Sciences, CXII (2015), 3020-3025; Lei Xu, Schmid, et al., "The Trophic Responses of Two Different Rodent-Vector-Plague Systems to Climate Change," Proceedings of the Royal Society of London B: Biological Sciences, CCLXXXII (2015), 20141846. David A. Eads and Dean E. Biggins, "Paltry Past-Precipitation: Predisposing Prairie Dogs to Plague?” Journal of Wildlife Management, LXXXI (2017), 990-998.

${ }^{33}$ For precipitation and settlement, see, for example, McCormick, Büntgen, et al., "Climate Change during and after the Roman Empire," 206; Pinke, Ferenczi, et al., "Settlement Patterns as Indicators of Water Level Rising? Case Study on the Wetlands of the Great Hungarian Plain,” Quaternary International, CDXV (2016), 204-215; idem et al., "Zonal assessment.”

${ }^{34}$ For a detailed discussion of the value of collaborative effort before the collection of evidence, see Izdebski, Holmgren, et al., "Realising Consilience: How Better Communication between Archaeologists, Historians and Natural Scientists Can Transform the Study of Past Climate Change in the Mediterranean," Quaternary Science Reviews, CXXXVI (2016), 5-22. The Historical Ice Core Project has the generous support of Arcadia, a charitable fund of Lisbet Rausing and Peter Baldwin. 